\title{
Bupivacaine versus tramadol: a clinical comparison of two anaesthetics administered via epidural route for postoperative analgesic effect in gynaecological surgeries
}

\author{
Md. Arshad Imam ${ }^{1}$, Sabir Hasnat ${ }^{2}$ \\ ${ }^{1}$ Associate Professor, ${ }^{2}$ Assistant Professor, Department of Anaesthesiology, Katihar Medical College, Katihar, Bihar, \\ India
}

Received: 03 April 2016

Accepted: 10 May 2016

*Correspondence:

Dr. Md. Arshad Imam,

E-mail:drarshadimam@rediffmail.com

Copyright: (c) the author(s), publisher and licensee Medip Academy. This is an open-access article distributed under the terms of the Creative Commons Attribution Non-Commercial License, which permits unrestricted non-commercial use, distribution, and reproduction in any medium, provided the original work is properly cited.

\begin{abstract}
Background: Gynaecological surgeries are associated with significant postoperative pain. The pain is usually of a long duration. Caudal epidural block has been considered as a procedure of choice for pain relief in such cases. This study was conducted to evaluate postoperative analgesic efficacy of four doses of epidurally administered Bupivacaine versus tramadol in gynaecological surgeries.

Methods: 40 adult cases ranging in age from 20 to 60 years with ASA Grade I \& II, presenting for elective gynaecological surgery. Cases were randomly allocated into two groups containing 20 cases each. Cases in Group B received $10 \mathrm{ml}$ of $0.25 \%$ Bupivacaine and those in Group T received Tramadol $100 \mathrm{mg}$ in $10 \mathrm{ml}$ of normal saline.

Results: Cases in Group T receiving epidural Tramadol had significant lower pain score on VAS as well as during 24 hours of observation. These cases also had significantly longer dosage intervals compared to Group B cases receiving Bupivacaine. Cardiovascular parameters were stable and similar between both groups.

Conclusions: Epidural Tramadol has better postoperative analgesic efficacy than epidural Bupivacaine. It is a potent and effective postoperative analgesic with rapid onset and minimum side effects.
\end{abstract}

Keywords: Analgesic, Bupivacaine, Gynaecological, Epidural, Postoperative, Tramadol

\section{INTRODUCTION}

Gynaecological surgeries are often associated with pain sensation for a long duration. Pain itself is a highly unpleasant sensory and emotional experience. ${ }^{1}$ Treatment of postoperative pain remains an important goal for anaesthetists in management of cases. Caudal epidural block remains a popular and conventional anaesthetic tool for control of such pain. Bupivacaine is the currently available local anaesthetics with long duration of action and its maximum analgesic effect is upto 6-12 hours. ${ }^{2,3}$ Several clinical methods and techniques have been implemented to extend the duration of regional anaesthesia with local anaesthetics. Placement of catheter invites a high risk of infection. ${ }^{4}$ Many drugs including epinephrine, opioids, clonidine, ketamine, midazolam and neostigmine have been tried as adjuvants with caudal bupivacaine to improve the quality of analgesia and extend its duration but each of these has its own documented adverse effects. ${ }^{5}$ The primary aim of this study was to compare the pharmacological analgesic efficacy of four different doses of tramadol $100 \mathrm{mg}$ versus bupivacaine $0.25 \%$ used separately in postoperative pain management of forty adult cases of gynaecological surgery and identify which drug at which dose had maximum duration of epidural analgesia. 


\section{METHODS}

The study designed was a blind study. Cases were randomly allocated into two groups containing 20 cases each. The present study was carried out in the Department of Anaesthesiology, Katihar Medical College and Hospital, Katihar. After obtaining ethical clearance from the Institutional Ethics Committee and obtaining written consents from the participants. 40 adult cases ranging in age from 20 to 60 years with ASA Grade I \& II requiring elective gynaecological surgery under epidural anaesthesia were selected for this prospective, randomized, double cases in Group B received Bupivacaine $0.25 \%$ and those in Group $\mathrm{T}$ received Tramadol 100mg.

\section{Inclusion criteria}

All stable cases requiring elective gynaecological surgery

\section{Exclusion criteria}

- Cases who did not want to participate in this study.

- Cases who had a contraindication to use of Bupivacaine or Tramadol.

- Cases with history suggestive of cardio-respiratory illness.

- Cases with history of drug sensitivity to the drugs in this study.

- Cases with pre-existing neurologic, spinal or sacral degenerations.

- Cases with infection at or around the site of injection.

- Cases with existing increased intracranial or intraocular pressure.

- Cases receiving medications likely to have interaction with opioids.

- Cases who were pregnant or lactating.

- Cases who were receiving anticoagulant or monoamine oxidase inhibitor therapy.

All cases were briefed and examined one day before the study. The epidural technique was explained to them. They were told that in case of failure of epidural anaesthesia they would be induced with general anaesthesia in that case they would automatically be removed from the study. All cases were directed to remain nil by mouth from the morning of the study. They were premedicated with $5 \mathrm{mg}$ Diazepam orally on the night before surgery. All cases were preloaded with $1000 \mathrm{ml}$ of Ringer's Lactate trough a $16 \mathrm{G}$ intravenous cannula before proceeding for the operation theatre. Equipments for both epidural and general anaesthesia were kept prepared in the operation theatre. For administration of epidural anaesthesia, 18G Tuohy needle an epidural catheter were prepared. In conventional position for spinal anaesthesia the L3-L4 intervertebral space was marked and a small wheal was made by subcutaneous infiltration of $2 \mathrm{ml}$ of $2 \%$ lignocaine. A small nick was then made over the wheal and the $18 \mathrm{G}$
Tuohy needle was introduced until the ligamentum flavum was pierced. The stylette was withdrawn and a $5 \mathrm{ml}$ glass syringe with smoothly moving piston was attached tightly to the hub of the Tuohy needle. The needle was slowly moved until there was loss of resistance. This indicated the epidural space. The catheter was then threaded to the epidural space and the needle was removed. The catheter was then fixed with a transparent occlusive dressing and $15 \mathrm{ml}$ of $2 \%$ xylocaine was injected through the catheter. This produced desirable anaesthesia for the surgeon to perform surgery. Post surgery the cases were transferred to the postoperative ward for pain management and resuscitation. The cases were now randomly allocated to one of the study groups. The drugs under this study were randomly injected when analgesic effect was demanded by the subject. This was the first dose and the time was recorded. Each case was visited at 2nd, 4th, 8th, 12th and 24 hours after the first dose. At each visit the VAS score was recorded along with pulse rate, blood pressure and breathing rate. The drug was repeated on demand by the cases and time of each additional dose was recorded. A maximum of four doses of each drug were permissible under this study and cases with sever persistent pain were given a rescue dose of $75 \mathrm{mg}$ intravenous Pethidine and excluded from the study being considered a failure case. The time of administration of rescue dose was also noted. After 24 hours, the epidural catheter was removed and pain management was left at the discretion of the attending specialist.

\section{RESULTS}

40 adult cases ranging in age from 20 to 60 years with ASA Grade I \& II, requiring elective gynaecological surgery under epidural anaesthesia were selected for this study. Cases were randomly allocated into two groups containing 20 cases each. Cases in Group B received Bupivacaine $0.25 \%$ and those in Group $\mathrm{T}$ received Tramadol 100mg.

From Table 1 it was observed that the cases in both groups were comparable on the basis of mean age being 41.35 years and SD 10.51 (Group B) and mean age of 41.85 years and SD 10.97 (Group T).

Table 2 shows that the cases in both groups were comparable on the basis of type of gynaecological surgery performed.

Table $3 \mathrm{~A}$ and $3 \mathrm{~B}$ explains the mean interval between $1^{\text {st }}$ $2^{\text {nd }}$ dose in Group B was 274.55 with SD 45.63 and in Group $\mathrm{T}$ was 401.65 with SD 72.15. Dose intervals between $2^{\text {nd }}-3^{\text {rd }}$ dose in Group B was 285.67 with SD 36.21 and in Group T was 379.64 with SD 54.37. Dose intervals between $3^{\text {rd }}-4^{\text {th }}$ dose in Group B was 273.42 with SD 25.71 and in Group $\mathrm{T}$ was 344.22 with SD 26.46. Between $4^{\text {th }}-$ rescue dose 6 cases and 2 cases were observed in Group B and Group T respectively. It was observed that mean interval between $1^{\text {st }}-2^{\text {nd }}$ dose in 
Group B was 274.55 with SD 45.63 and in Group T was 401.65 with SD 72.15. Dose intervals between $2^{\text {nd }}-3^{\text {rd }}$ dose in Group B was 285.67 with SD 36.21 and in Group $\mathrm{T}$ was 379.64 with SD 54.37. Dose intervals between $3^{\text {rd }}$ $-4^{\text {th }}$ dose in Group B was 273.42 with SD 25.71 and in Group T was 344.22 with SD 26.46. Between $4^{\text {th }}-$ rescue dose 6 cases and 2 cases were observed in Group B and Group $\mathrm{T}$ respectively. Table 4 shows that rescue dose was required in 6 cases in Group B and in only 2 cases in Group T. Table 5 displays that higher dose intervals were observed in Group $\mathrm{T}$ and Table 6 clarifies that most common side effect of Nausea - Vomiting was observed in 12 cases in Group T.

Table 1: Age in years of each participant in each group.

\begin{tabular}{|lll|}
\hline Case No. & $\begin{array}{l}\text { Group B } \\
\text { (Bupivacaine) }\end{array}$ & $\begin{array}{l}\text { Group T } \\
\text { (Tramadol) }\end{array}$ \\
\hline $\mathbf{0 1}$ & 29 & 30 \\
\hline $\mathbf{0 2}$ & 28 & 45 \\
\hline $\mathbf{0 3}$ & 41 & 57 \\
\hline $\mathbf{0 4}$ & 54 & 47 \\
\hline $\mathbf{0 5}$ & 52 & 37 \\
\hline $\mathbf{0 6}$ & 38 & 58 \\
\hline $\mathbf{0 7}$ & 39 & 28 \\
\hline $\mathbf{0 8}$ & 51 & 60 \\
\hline $\mathbf{0 9}$ & 59 & 46 \\
\hline $\mathbf{1 0}$ & 37 & 51 \\
\hline $\mathbf{1 1}$ & 48 & 54 \\
\hline $\mathbf{1 2}$ & 54 & 29 \\
\hline $\mathbf{1 3}$ & 28 & 41 \\
\hline $\mathbf{1 4}$ & 42 & 35 \\
\hline $\mathbf{1 5}$ & 55 & 24 \\
\hline $\mathbf{1 6}$ & 29 & 36 \\
\hline $\mathbf{1 7}$ & 36 & 39 \\
\hline $\mathbf{1 8}$ & 24 & 29 \\
\hline $\mathbf{1 9}$ & 43 & 51 \\
\hline $\mathbf{2 0}$ & 40 & 40 \\
\hline
\end{tabular}

Table 2: Types of gynaecological surgeries performed on the cases under study.

\begin{tabular}{|llll|}
\hline S. No. & Operation & $\begin{array}{l}\text { Group } \\
\text { B }\end{array}$ & $\begin{array}{l}\text { Group } \\
\text { T }\end{array}$ \\
\hline $\mathbf{0 1}$ & $\begin{array}{l}\text { Total abdominal } \\
\text { hysterectomy }\end{array}$ & 6 & 8 \\
\hline $\mathbf{0 2}$ & Vaginal hysterectomy & 2 & 2 \\
\hline $\mathbf{0 3}$ & $\begin{array}{l}\text { Hysterotomy and tubal } \\
\text { ligation }\end{array}$ & 6 & 6 \\
\hline $\mathbf{0 4}$ & $\begin{array}{l}\text { Repair of Cervix/ } \\
\text { Fistula/ Pelvic Floor }\end{array}$ & 4 & 3 \\
\hline $\mathbf{0 5}$ & Exploratory laparotomy & 2 & 1 \\
\hline
\end{tabular}

Table 3A: Table showing dosage intervals in minutes in group $\mathbf{B}$.

\begin{tabular}{|lllll|}
\hline $\begin{array}{l}\text { S. } \\
\text { No. }\end{array}$ & $\begin{array}{l}\mathbf{1}^{\text {st }}-\mathbf{2}^{\text {nd }} \\
\text { Dose }\end{array}$ & $\begin{array}{l}\mathbf{2}^{\text {nd }}-\mathbf{3}^{\text {rd }} \\
\text { Dose }\end{array}$ & $\begin{array}{l}\mathbf{3}^{\text {rd }}-\mathbf{4}^{\text {th }} \\
\text { Dose }\end{array}$ & $\begin{array}{l}\mathbf{4}^{\text {th }}- \\
\text { Rescue } \\
\text { Dose }\end{array}$ \\
\hline $\mathbf{0 1}$ & 304 & 314 & NIL & NIL \\
\hline $\mathbf{0 2}$ & 214 & 204 & 300 & NIL \\
\hline $\mathbf{0 3}$ & 322 & NIL & NIL & NIL \\
\hline $\mathbf{0 4}$ & 244 & 260 & 306 & NIL \\
\hline $\mathbf{0 5}$ & 292 & 312 & 284 & NIL \\
\hline $\mathbf{0 6}$ & 304 & 298 & 268 & NIL \\
\hline $\mathbf{0 7}$ & 281 & 326 & 292 & NIL \\
\hline $\mathbf{0 8}$ & 222 & 322 & 304 & NIL \\
\hline $\mathbf{0 9}$ & 302 & 286 & 282 & NIL \\
\hline $\mathbf{1 0}$ & 294 & 282 & 278 & 292 \\
\hline $\mathbf{1 1}$ & 264 & 300 & 276 & NIL \\
\hline $\mathbf{1 2}$ & 254 & 240 & 248 & 304 \\
\hline $\mathbf{1 3}$ & 352 & NIL & NIL & NIL \\
\hline $\mathbf{1 4}$ & 240 & 310 & NIL & NIL \\
\hline $\mathbf{1 5}$ & 198 & 244 & 220 & 372 \\
\hline $\mathbf{1 6}$ & 305 & 298 & 274 & NIL \\
\hline $\mathbf{1 7}$ & 362 & 340 & NIL & NIL \\
\hline $\mathbf{1 8}$ & 250 & 250 & 264 & 309 \\
\hline $\mathbf{1 9}$ & 212 & 254 & 232 & 354 \\
\hline $\mathbf{2 0}$ & 274 & 300 & NIL & NIL \\
\hline & & & & \\
\hline
\end{tabular}

Table 3B: Table showing dosage intervals in minutes in group $\mathbf{T}$.

\begin{tabular}{|lllll|}
\hline $\begin{array}{l}\text { S. } \\
\text { No. }\end{array}$ & $\begin{array}{l}\mathbf{1}^{\text {st }}-\mathbf{2}^{\text {nd }} \\
\text { Dose }\end{array}$ & $\begin{array}{l}\mathbf{2}^{\text {nd }}-3^{\text {rd }} \\
\text { Dose }\end{array}$ & $\begin{array}{l}3^{\text {rd }}-4^{\text {th }} \\
\text { Dose }\end{array}$ & $\begin{array}{l}4^{\text {th }}- \\
\text { Rescue } \\
\text { Dose }\end{array}$ \\
\hline $\mathbf{0 1}$ & 480 & 420 & NIL & NIL \\
\hline $\mathbf{0 2}$ & 508 & NIL & NIL & NIL \\
\hline $\mathbf{0 3}$ & 398 & 364 & NIL & NIL \\
\hline $\mathbf{0 4}$ & 384 & 402 & 350 & NIL \\
\hline $\mathbf{0 5}$ & 528 & NIL & NIL & NIL \\
\hline $\mathbf{0 6}$ & 374 & 396 & NIL & NIL \\
\hline $\mathbf{0 7}$ & 338 & 354 & 362 & NIL \\
\hline $\mathbf{0 8}$ & 290 & 340 & 354 & 384 \\
\hline $\mathbf{0 9}$ & 464 & 480 & NIL & NIL \\
\hline $\mathbf{1 0}$ & 388 & 368 & 370 & NIL \\
\hline $\mathbf{1 1}$ & 362 & 396 & 380 & NIL \\
\hline $\mathbf{1 2}$ & 269 & 300 & 312 & 380 \\
\hline $\mathbf{1 3}$ & 474 & 448 & NIL & NIL \\
\hline $\mathbf{1 4}$ & 310 & 248 & 300 & NIL \\
\hline $\mathbf{1 5}$ & 396 & 382 & NIL & NIL \\
\hline $\mathbf{1 6}$ & 382 & 364 & 340 & NIL \\
\hline $\mathbf{1 7}$ & 394 & 358 & 330 & NIL \\
\hline $\mathbf{1 8}$ & 390 & 424 & NIL & NIL \\
\hline $\mathbf{1 9}$ & 502 & NIL & NIL & NIL \\
\hline $\mathbf{2 0}$ & 400 & 410 & NIL & NIL \\
\hline
\end{tabular}


Table 4: Frequency of dose administration.

\begin{tabular}{|lll|}
\hline $\begin{array}{l}\text { No. of doses } \\
\text { required }\end{array}$ & Group B $(\boldsymbol{n = 2 0})$ & Group T $(\boldsymbol{n}=\mathbf{2 0})$ \\
\hline One & NIL & NIL \\
\hline Two & 2 & 3 \\
\hline Three & 4 & 8 \\
\hline Four & 8 & 7 \\
\hline Rescue & 6 & 2 \\
\hline
\end{tabular}

Table 5: Comparison of mean dosing intervals.

\begin{tabular}{|llll|}
\hline S. No. & Interval & $\begin{array}{l}\text { Group B } \\
\text { (minutes) }\end{array}$ & $\begin{array}{l}\text { Group T } \\
\text { (minutes) }\end{array}$ \\
\hline $\mathbf{1}$ & $1^{\text {st }}-2^{\text {nd }}$ & 274.55 & 401.65 \\
\hline $\mathbf{2}$ & $2^{\text {nd }}-3^{\text {rd }}$ & 379.64 & 385.66 \\
\hline $\mathbf{3}$ & $3^{\text {rd }}-4^{\text {th }}$ & 344.22 & 273.42 \\
\hline $\mathbf{4}$ & $\begin{array}{l}4^{\text {th }}- \\
\text { Rescue }\end{array}$ & 382.00 & 326.00 \\
\hline
\end{tabular}

Table 6: Incidence of side effects.

\begin{tabular}{|llll|}
\hline $\begin{array}{l}\text { S. } \\
\text { No. }\end{array}$ & Side effect & $\begin{array}{l}\text { Group B } \\
(\boldsymbol{n}=\mathbf{2 0})\end{array}$ & $\begin{array}{l}\text { Group T } \\
(\boldsymbol{n}=\mathbf{2 0})\end{array}$ \\
\hline $\mathbf{1}$ & Nausea - Vomiting & 4 & 12 \\
\hline $\mathbf{2}$ & $\begin{array}{l}\text { Numbness in lower } \\
\text { limbs }\end{array}$ & 3 & NIL \\
\hline $\mathbf{3}$ & Shivering & 2 & NIL \\
\hline $\mathbf{4}$ & Respiratory depression & NIL & NIL \\
\hline $\mathbf{5}$ & Pruritus & NIL & NIL \\
\hline $\mathbf{6}$ & Dizziness & 4 & 3 \\
\hline $\mathbf{7}$ & Bowel pain & NIL & NIL \\
\hline $\mathbf{8}$ & $\begin{array}{l}\text { Generalized burning } \\
\text { sensation }\end{array}$ & NIL & NIL \\
\hline $\mathbf{9}$ & $\begin{array}{l}\text { Inability to walk after } \\
\text { 24 hour period }\end{array}$ & 8 & 2 \\
\hline
\end{tabular}

\section{DISCUSSION}

In our present study we found lower VAS pain scores and a longer duration of postoperative analgesia and a much significant decrease in the $24 \mathrm{~h}$ consumption of rescue anaesthesia in Group T. There was also earlier recovery of unassisted ambulation and home discharge. ${ }^{8}$ No significant side effects were detected in any group. Although tramadol was initially considered to be a weak $\mu$-opioid agonist, it appears to have multimodal mechanisms of action. It is now accepted that in addition to $\mu$-opioid agonist effect, tramadol enhances the function of the spinal descending inhibitory pathway by inhibition of reuptake of both 5-hydroxytryptamine (5HT) and norepinephrine, together with pre-synaptic stimulation of H-HT release. ${ }^{9,10}$

The local anaesthetic action of tramadol remains unproven. 5-HT3 receptors are exposed on the peripheral and spinal terminals of the nociceptive primary afferent fibers as well as on the superficial lamina of the dorsal horn which indicates possible peripheral sites of action of tramadol. ${ }^{11,12}$ Studies have shown a definitive local anaesthetic effect of tramadol in experiments on frog sciatic nerves revealing that the nerve conduction block of tramadol is 3-6 times weaker than that of lidocaine. Although lidocaine inhibits $\mathrm{Na}+$ channels, it is suggested that tramadol inhibits $\mathrm{K}+$ channels.

Headache, nausea, vomiting, dizziness, somnolence are major side effects of IV tramadol when used for postoperative analgesia. ${ }^{13}$ Such incidence seems to be directly related to peak serum concentration levels of tramadol. Activation of hypothalamo-pituitary-adrenal axis and rise of cortisol and epinephrine plasma levels associated with surgical trauma re very important postoperative stress responses. Caudal tramadol has more analgesic efficacy than bupivacaine. ${ }^{14}$ In equipotent analgesic doses of tramadol to morphine is free of respiratory symptoms. ${ }^{15}$

\section{CONCLUSION}

The present study concluded that both epidurally administered bupivacaine and tramadol are safe and effective postoperative analgesics. Postoperative consumption of analgesic was higher in the Bupivacaine group. Epidural tramadol $100 \mathrm{mg}$ in $10 \mathrm{ml}$ provides better and longer duration of anaesthesia with rapid onset and no incidence of complications.

\section{Funding: No funding sources}

Conflict of interest: None declared

Ethical approval: The study was approved by the institutional ethics committee

\section{REFERENCES}

1. Farag HM, Esmat IM. Efficacy of two doses of Tramadol versus Bupivacaine in perioperative caudal analgesia in adult hemorrhoidectomy. Saudi J Anaesth. 2016;10:138-42.

2. Rowney DA, Doyle E. Epidural and subarachnoid blockade in shildren. Anaesthesia. 1998;53:9801001.

3. Broadman LM, Hannallah RS. Experience with 1154 consecutive cases without complications. Anaesth Anal. 1987;66:848-54.

4. Dalens BJ. Regional anaesthesia in children. In: Miller RD, editor. Anaesthesia. 5th ed. Vol 1549. Philadelphia: Chirchill Livingstone; 2000:85.

5. Krane EJ, Jacobson LE. Caudal morphine for analgesia in children: A comparison with caudal bupivacaine and intravenous morphine. Anaesth Analg. 1987;66:647-53.

6. Hansen TG, Hennerberg SW, Lund J. Caudal bupivacaine supplemented with caudal or intravenous clonidine in children undergoing hypospadias repair. Br J Anaesth. 2004;92:223-7.

7. Kumar P, Rudra R, Pan AA, Asharia A. Caudal additives in paediatrics: a comparison among 
midazolam, Ketamine and neostigmine coadministered with bupivacaine. Anaesth Analg. 2005;101:69-73.

8. Zeidan A, KAssem R, Nahleh N, Maaliki $H$. Intraarticular Tramadol-Bupivacaine combination prolongs the duration of postoperative analgesia after outpatient arthroscopic knee surgery. Anaesth Analg. 2008;107(1):292-9.

9. Arcioni R, Rocca M, Romano S, Romano R. Ondansetron inhibits the analgesic effects of tramadol: a possible 5HT(3) spinal receptor involvement in acute pain in humans. Anesth Anal. 2002;94:1553-7.

10. MErt T, Gunyes Y, Guven M, gunay I. Differential effects of lignocaine ad tramadol on modified nerve impulse by 4 -aminopyridine in rats. Pharmacology. 2003;69:68-73.

11. Davidson C, Langford RM. Actions of tramadol, its enantiomere and principal metabolite, Odesmethyltramadol, on serotonine (5-HT) efflux and uptake in the rat dorsal raphe nucleus. Br J Anaesth. 1997;79:352-6.

12. Kayser V, Besson JM. Evidence for noradrenergic component in the antinociceptive effect of the analgesic agent tramadol I an animal model of clinical pain, the arthritic rat. Eur J Pharmacol. 1992;224:83-8.

13. Shipton EA. Tramadol: present and future. Anaesth Intensive Care. 2000;28:363-74.

14. Okzan S, Pocan S, Bahar A. The effect of caudal bupivacaine versus tramadol in postoperative analgesia for paediatric patients. J Int Med Res. 2003;31:497-502.

15. Grond S, Sablotzki. Clinical pharmacology of tramadol. Clin Pharmacokinet. 2004;43:879-923.

Cite this article as: Imam MA, Hasnat S. Bupivacaine versus tramadol: a clinical comparison of two anaesthetics administered via epidural route for postoperative analgesic effect in gynaecological surgeries. Int J Adv Med 2016;3:602-6. 